\title{
Studying the Factors Affecting Consumers Complicity with Counterfeit Products
}

\author{
Aidin Bavar (Corresponding author) \\ Department of Business Management, Islamic Azad University, Central Tehran Branch, \\ Tehran, Iran
}

Tel: 98-912-526-4200Ｅ-mail: AidinBavar@gmail.com

Hamid Tahmasebifard

Department of Business Management, Islamic Azad University, Central Tehran Branch, Tehran, Iran

Tel: 98-912-304-5548Ｅ-mail: Ham.tahmasebifard.mng@iauctb.ac.ir

\begin{abstract}
Bahram Kheiry
Department of Business Management, Islamic Azad University, Central Tehran Branch, Tehran, Iran

Tel: 98-912-359-6803Ｅ-mail: bahramkheiri@gmail.com
\end{abstract}

Received: Jan. 25, 2017 Accepted: Jan. 30, 2016 Published: May 15, 2017

doi:10.5296/bms.v8i1.10648ＵRL: https://doi.org/10.5296/bms.v8i1.10648

\begin{abstract}
Manufacturing and using counterfeit products has seriously damaged industries worldwide. Consciously complicity of consumers in buying these products is an interesting issue which on the light of its impression on economies and operation continuity of businesses, necessitates more investigation. Thus, thus study aims for investigating factors affecting consumer complicity in buying and consuming counterfeits. To this end, a questionnaire survey of students in management universities was conducted using random simple sampling. 385 questionnaires received and analyzed through descriptive statistics and structural
\end{abstract}




\section{Macrothink}

Business Management and Strategy ISSN 2157-6068 2017, Vol. 8, No. 1

equation modeling. Results showed that hedonic shopping experience and perceived quality affects positively consumer complicity. But collectivism and ethical consideration do not lay any influence on consumer complicity.

Keywords: Counterfeit, Complicity, Hedonic shopping experience, Collectivism 


\section{Introduction}

Counterfeiting is an important and growing issue all over the world, which takes place both in less developed countries and also in developed countries. Counterfeits are products that produce a brand which is similar to a known brand or which can't be distinguished from that specific brand and thus violates the rights of the brand owners (Bian and Moutinho, 2011). Today, production of this group of products is on the rise and the producers of this group of products seek financial gains by producing products similar to the original design.

According to Eisend and Schuchert-Güler (2006), these phenomena have drastically increased over the last three decades. The value of counterfeits in the global market has grown by $1100 \%$ in the years between 1984 and 1994 . Counterfeits reached $7 \%$ of the world trade and 512 billion dollars in 2004 (Bian and Moutinho, 2011). According to Chaudhry et al., (2005) in America's economy the cost of counterfeiting for each year has been estimated as more than 200 billion dollars. Based on International AntiCounterfeiting Coalition (IACC) and International Intellectual Property Institute (IIPI) approximately 5\% of products all over the world are counterfeits (De Matos et al., 2007).

What has today drawn attention regarding the use of counterfeits is consumers' conscious use of these products. Studies show that the demand for such products is increasing and the consumers that consciously use this group of products seem satisfied with their work. The reasons for the consumers' conscious use of counterfeits and also their satisfaction with using these products and goods has become a major concern for researchers. The main research question, with regard to the above issues, is posed as follows: "What factors affect consumer complicity in buying counterfeits?"

In general, the main goal of research is to provide a combined model which investigates and determines the factors affecting consumer complicity with counterfeit.

\section{Literature Review}

\subsection{Research Background}

Counterfeiting of products is basically any illegal production and distribution of goods that have protected exclusive rights such as copyright (brands, logos, designs and copyright). According to Eisend and Schuchert-Güler (2006), counterfeits are products that produce a brand which is similar to a known brand or which can't be distinguished from that specific brand and thus violates the rights of the brand owners (Bian and Moutinho, 2011).

Production of counterfeits refers to any unauthorized production or when goods with special features supported by intellectual property (IP) rights (brands, scores and copyrights) are distributed (Chaudhry and Stumpt, 2011).

According to Eisend and Schuchert-Güler (2006), using counterfeits is not a new phenomenon, but this phenomenon has increased over the last two or three decades. The Turnover of counterfeits in the global market has grown by approximately $1100 \%$ in the years 
between 1984 and 1994. Counterfeits reached 512 billion dollars for 7\% of the world trade in 2004 (Bian and Moutinho, 2011).

In America's economy the cost of counterfeiting for each year has been estimated as more than 200 billion dollars. Based on IACC (2005) and IIPI (2003), approximately 5\% of products all over the world are counterfeits (de Matos et al., 2007). In Iran also, like the other countries in the world, counterfeits have become a widespread and major problem. In this respect, non-original and fake goods can be mentioned in particular, the origin of most of which is China. In order to solve this problem, numerous activities and laws have been conducted, among which the Anti-Smuggling Act can be mentioned which was passed by the Parliament in 2012. However, it should be noted that most of these actions mostly concern the good supply party and they have less frequently considered the good demand party; yet new measures are being taken which show attention to the demand party. Namely, "Shabnam" project can be mentioned which has been implemented by the Ministry of Trade. In this project which is carried out with the goal of expanding the inspections, consumers can identify the counterfeit using a camera-equipped mobile phone and related software and notify the authorities (Shabnam.ir). This issue shows the fact that attention to the demand party is growing and that it is society's need today. However, the level of actual efficiency of this project for achievement of the assumed goal of its design is another issue in itself.

Global trends show that an alarming growth is taking place in the field of production, distribution and consumption of counterfeits. Trade of counterfeits has been estimated to be over 600 billion dollars per year all over the world. This amount has faced a dramatic growth rate in the last 20 years. Nevertheless, this growth is mostly due to the growing demand for its consumption. Counterfeiting is an important issue which has become a serious problem in both developing and also developed countries. The phenomenal growth of duplication creates serious social and economic problems which pose a threat to the consumers' life. Counterfeiting creates negative effects on the state tax revenues, irregularities in the market and economic development (Lee, 2009), but if a person's approach to a counterfeit is favorable, it is highly probable that they consider buying counterfeits (Wee et al., 1995).

Reports show that the effects of counterfeiting include economic and social effects (innovation and growth, criminal activities, environment, employment, foreign direct investment and trade), effects on employment rights (the volume of sales and prices and costs, value of brand, the company's reputation, loyalties, investment in the company, costs of the field of operations), effects on the consumers (health and safety risk and dangers and consumer's utility) and effects on the government (expenses and bribery) (OECD, 2007). The consequences of consumers' participation in the counterfeits can overshadow the trade of known products in our country, such as saffron, carpets and dried fruits, whose cost of production in some exchange rates and whose labor cost is lower.

The actual costs of counterfeiting are not limited to loss of income and revenue from sales. The overall costs of counterfeiting also include reduction of sales by producers in the long term, and due to the loss from imitating the brand and consequently the consumer's 
unpleasant experience of consuming a counterfeit which they have assumed to be original, the distinction and special value of the brand is also harmed. Costs that are created at the social level include losses in employment, loss of income and proceeds from sales tax and costs related to increased trade deficits. According to an assessment, counterfeiting leads to the loss of 750,000 jobs (Berman, 2008).

\subsection{Theoretical Foundation and conceptual Development}

According to Husted (2001), Hofstede (1980), early in his work when the concept of collectivism was founded (as opposed to individualism), in several studies used it as a background for prediction of the tendencies to buy counterfeits, under the assumption that the ideology of collectivism and determination of the concept of sharing will increase the consumers' tendency to obtain counterfeits. According to Wang et al., (2005) a Chinese proverb says: "One who shares is rewarded, one who doesn't is condemned". This proverb has been used as an image of how a value of collectivism can shape the philosophy of individual ethics regarding buying counterfeits. In general, the structure of collectivism will have a significant effect on consumer complicity in buying counterfeits (Chaudhury and Stumpf, 2011).Therefore, the following hypothesis can be proposed:

H1: Collectivism has a positive effect on consumer complicity.

According to Hirschman and Holbroock (1982) and also Babin et al., (1994), based on the studies conducted on the consumer's hedonic shopping behavior, researchers have concluded that consumers have been stimulated by means of illegal behaviors in connection with trade of counterfeits both in physical stores and also in virtual stores. According to Eisend and Schuchert-Güler (2006), Gentry et al., (2006) and Penz \& Stöttinger (2008), different sales environments allow researchers to assess the validity of consumer's hedonic shopping experience and whether they have experienced the sense of danger from their illegal behavior. There are also studies on consumer complicity which consider luxury goods as entertaining and worth the price, regardless of the fact that they are counterfeit or original products; and also, the fact that mental state is also a variable that affects the shopping decision and adjusts the consumers' attitude to counterfeits; and also, the fact that counterfeits are new and symbolic of tourist experiences (Chaudhury and Stumpf, 2011).

Thus, the following hypothesis can be proposed:

H2: Hedonic shopping experience has a positive effect on consumer complicity in buying counterfeits.

Ethical considerations reflect the consumer's level of agreement with this issue that violations of complicity on IP rights of the product owner both harm the industry and also seem illegal or unethical. According to Lysonski and Doroazola (2008), the conducted studies show several types of ethical considerations, including consumers' perception of ethics or laws related to commitment of an act of complicity. Recent studies have concluded that this approach by the consumer (the fact that they are made upset by the theft of audio works as an 
unethical and illegal issue) has been a considerable prediction of the future of consumer complicity. According to him and his colleagues (1995), previous studies have shown that consumers, for various reasons, intend to buy counterfeits; namely, expression of a sense of hostility to big businesses and having a lax attitude about the legal protection of IP rights (Chaudhry and Stumpf, 2011).

Therefore, the following hypothesis can be proposed:

H3: Ethical considerations have a negative effect on consumer complicity in buying counterfeits.

According to Eisend and Schuchert-Güler (2006), some researchers believe that if consumers recognize a high quality of the product prior to shopping, their tendency for obtaining counterfeits increases. According to Gentry et al., (2006) other researchers propose the issue of "consumer confusion", which based on the quality chain of the counterfeits created, whether low-quality counterfeits or authentic goods, is similar to surplus productions that have been sold through unauthorized channels. According to de Matos et al., (2007), Penz and Stöttinger (2008), most studies have shown that due to the weighing of price and quality by consumers, perceived quality of counterfeits increases the consumer tendency to obtain it. In fact, some researchers have claimed that consumers who have bought the counterfeits have not believed that these products are of low quality compared with the original products (Chaudhry and Stumpf, 2011).

Thus, the following hypothesis can be proposed:

H4: Perceived quality has a positive effect on consumer complicity in buying counterfeits.

Hedonic shopping experience acts through expectations for effort. When consumers feel that obtaining and using the product is easy without efforts or with less efforts, they will increase hedonic shopping. Therefore, a large amount of expectations for effort increases hedonic shopping (Yang, 2010).

Therefore, the following hypothesis can be proposed:

H5: Expectations for effort has a positive effect on hedonic shopping experience.

According to Wilcox et al., (2009), the role of the ethical approach that leads consumer behavior towards buying counterfeits is indicative of a background of consumer complicity. According to Shoham et al., (2008), two groups of ethical ideologies have been chosen in order to determine which of these two (idealism and relativism) has a stronger relationship with consumer complicity. According to Singh et al., (2007), this scale of idealism and relativism has been cited by the present researchers to develop their theories which are related to the consumers or managers' ethical behavior in the marketing environment. Dubinsky et al., (2005) have, in a study, assessed moral philosophy and ethical perception in consumers and have proved that consumers who are strongly relativist are less likely to oppose a situation that is ethically ambiguous, whereas consumers that are strongly idealist will oppose this. 
According to Gupta et al., (2004) and also Tan (2002), a consumer's tendency for participation in counterfeiting is due to lack of a large degree of moral intensity, and computer technology may also have a huge impact on this illegal action. Therefore, the following hypotheses can be proposed:

H6: Idealism has a positive effect on ethical considerations.

H7: Relativism has a negative effect on ethical considerations.

Perceived quality, based on the definition by Keller (2003), refers to a person's overall judgment of the precedence and advantages of a certain product or brand. Reputation is stability of performance over time and from one purchase to another (Broyles et al., 2010). A person's behavioral loyalty, as defined by Keller (2003), refers to the repeat purchase of a brand by them or the frequent purchase of a brand by a person. Reputation and behavioral loyalty are two variables which, based on the studies conducted, affect perceived quality by consumers. The reputation that consumers attach to the good they consume and also the loyalty that consumers have to the good they consume can increase perceived quality of the product by the consumer.

Thus, the following hypotheses can be proposed:

H8: Reputation has a positive effect on perceived quality.

H9: Behavioral loyalty has a positive effect on perceived quality.

According to the definition by Childers and Rao (1992) and also Keillor et al., (1996), the views of the buyer's family and other trusted people close to them affect their shopping decision (Gil et al., 2007). According to Childers and Rao (1992) and also Keillor et al. (1996), due to the importance of the information that is obtained from one product through the family, this information may determine the consumer's perceived quality of the product. Therefore, young people's perception of the products and brands that are recommended or consumed by other consumers may affect the perception of the quality of some products or brands. This issue is especially the case regarding the family, whose views are accepted by the youth as experienced buyers of certain products. According to Feltham (1998) and also Moor et al., (2002), this perception will bring about a more positive attitude towards the considered brand or product and may lead to the purchase of that specific brand or product (Gil et al., 2007). Therefore, the following hypothesis can be proposed:

H10: Family has a positive effect on perceived quality.

Price, based on the definition by Milgrom and Roberts (1986) and also Rao and Monroe (1989) refers to the determined value for a product or brand (Gil et al., 2007). According to Kirmani and Wright (1989), price plays the main role in the consumer's perception of the quality of the product. Also, according to Milgrom and Roberts (1986), Simon and Sullivan (1993) and Cobb-Walgren et al., (1995), price is also considered as a sign of perceived quality. Therefore, generally a higher quality is perceived for products that have a higher price than 
products that have a lower price. This has been proved in many studies (Gil et al., 2007). Thus, the following hypothesis can be proposed:

H11: Price has a positive effect on perceived quality.

Therefore, the conceptual model of research is as follows:

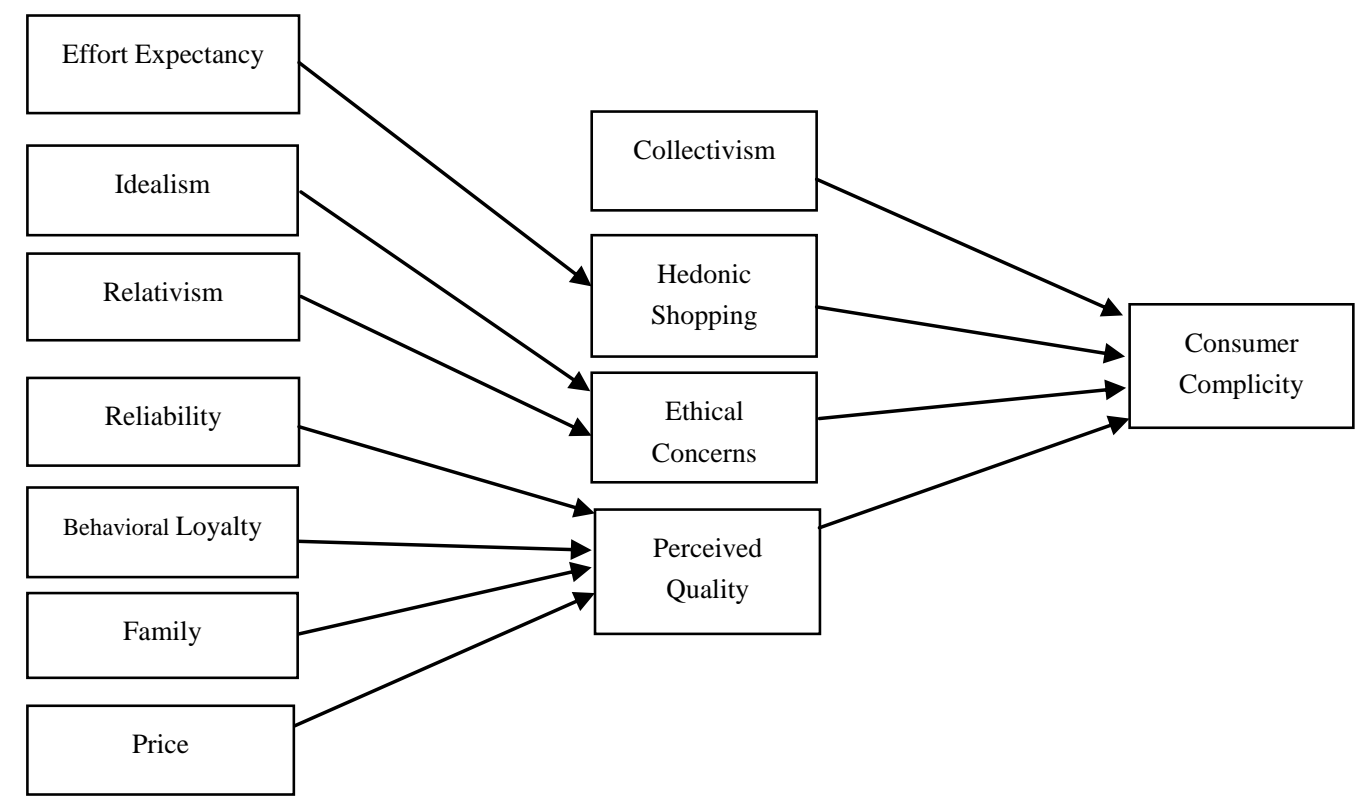

Fig.1. Conceptual model of research

\section{Data and Methods}

The type of study in terms of objective is applied, and the type of study in terms of research method is descriptive, survey and correlational. The type of study in terms of time is cross-sectional, and the type of study in terms of implementation or method of data collection is the field method. The type of study in terms of level of depth is extensive.

\subsection{The Statistical Population}

It is comprised of the students of three faculties of management from state universities in Tehran, which includes: Faculty of Management in Allameh Tabatabaei University, Faculty of Management in Tehran University, Faculty of Management in Shahid Beheshti University and also three faculties of management in Azad Universities of Tehran City including faculties of management in South-Tehran, Central-Tehran and North-Tehran Universities.

\subsection{Research Sampling Method}

The sampling method is stratified and the sample size, due to lack of cooperation of officials of faculties in which the questionnaire has been distributed and lack of exact information on the number of students of these 6 faculties and based on Krejcie and Morgan's (1970) table, assuming the maximum population size, is 385 individuals. In this study, the data is collected in the following methods: 
- Library studies: These are done by taking notes from books, articles, dissertations and using the Internet.

- Field method: Field studies examine the subjects in their natural conditions and include collection of initial and new information from the subjects themselves. In general, research by means of the questionnaire makes use of customers' views.

To prepare and design the questionnaire, besides using secondary sources which are available sources, the required information for the study has been collected through the questionnaire tool as the primary sources. The questions of the questionnaire are of the type of closed questions and the measurement scale of the questions has been of the type of Likert scale. For this study, a combination of several questionnaires was used which have been derived from translation of available questionnaires in the articles. The questions of this questionnaire have been translated from English to Persian and again to English.

The first part of the questionnaire includes personal information of the responders, which include gender, marital status, age, education and family income. The second part of the questionnaire focuses on the measurement of research constructs which the source of questions and the number of questions related to each construct are presented in the table below. Also, questionnaire's items presented in appendix 1.

Table 1. The questionnaire's items

\begin{tabular}{|c|l|c|}
\hline Construct & \multicolumn{1}{|c|}{ Resource } & $\begin{array}{c}\text { Questions' } \\
\text { numbers }\end{array}$ \\
\hline Idealism & Chaudhry, P. E and Stump,S. A (2011) & $1-5$ \\
\hline Relativism & Chaudhry and Stump (2011) & $6-10$ \\
\hline Collectivism & Chaudhry and Stump (2011) & $11-13$ \\
\hline Ethical concern & Chaudhry and Stump (2011) & $14-17$ \\
\hline Perceived quality & Chaudhry and Stump (2011)/ Gil et al.,(2007) & $18-20$ \\
\hline Hedonic shopping & Chaudhry and Stumpf (2011) & $21-29$ \\
\hline Consumer complicity & Chaudhry and Stumpf (2011) & $30-33$ \\
\hline price & Gil et al., (2007) & $34-36$ \\
\hline Family & Gil et al., (2007) & $37-41$ \\
\hline Effort expectancy & Yang (2010) & $42-44$ \\
\hline Behavioral loyalty & Tracey S. Dagger and Meredith E. David (2010) & $45-48$ \\
\hline Reliability & A.Parasuraman , Valarie A.Zeithaml and Leonard L.Berry & $49-52$ \\
\hline
\end{tabular}

\section{Results}

\subsection{Assessment of Validity}

\subsubsection{Face Validity}

In this study, to assess face validity, 17 questionnaires were distributed among the students of Faculty of Management in Azad University, Tehran-Central Branch, and there were no ambiguities and questions for the responders regarding the questions. 


\subsubsection{Content Validity}

In this study, to assess CVR, 9 questionnaires were distributed among the PhD students of the field of marketing management. The ratio of the obtained validity for all the questions of the aforementioned questionnaire, except for 2 questions, based on the table of minimum acceptable CVR according to the number of evaluators which has been estimated below, was acceptable and those questions were removed from the questionnaire.

\subsubsection{Construct Validity}

In this study, in order to examine the construct validity (structural), confirmatory factor analysis (CFA) was used. Construct validity shows whether the selected indicators for measuring their constructs are accurate or not. After implementing CFA in the software, if the factor load of each question with its construct has a significant t-value at the $5 \%$ level of error (i.e. its value is outside the 1.96 and -1.96 range) and also the factor load of each indicator with its construct is over 0.50 , then this indicator is accurate to measure that latent construct.

After implementing the model, the factor load related to the questions was considered as more than the threshold value of 0.50 . Therefore, it can be concluded that the questions assess their constructs accurately.

\subsection{Assessment of Reliability}

In this study, Cronbach's alpha method was used to calculate the reliability of the questionnaire, and the overall results indicate that the alpha value, for all the constructs, is a value more than 0.7 , which shows the reliability of the questionnaire and the responders' appropriate and equal mental perception of the content of the variables related to each construct. In methodology of SEM, composite reliability coefficient is used, and the values more than 0.6 for each construct show the good reliability of the research constructs.

\section{Discussion}

To analysis the data, we employed descriptive statistics and inferential statistics. Descriptive statistics are used by means of indicators such as mean, median and standard deviation for description of demographic variables and research variables, and inferential statistics are used to test the hypotheses by means of SEM method based on examining the simultaneous impact of independent and dependent variables.

To show this issue that the variables under study have the conditions of normal distribution, skewness and kurtosis test, which is also known as Kuran's test, was used and the results show normal distribution. This test has the null hypothesis based on normal distribution. When the level of significance is less than 0.05 , it indicates lack of normality of the variables under study. As all the levels of significance are above 0.05 , the null hypothesis based on normal distribution is accepted. Thus, the conditions of normality of the variables under study for estimation of the unknown parameters are reliable. 


\subsection{Descriptive Statistics}

Based on the information collected from the research questionnaires, 231 individuals under study are comprised of women's group with $60 \%$ of the sample and men's group has formed 154 individuals equal to $40 \%$ of the population. The highest number of responders in terms of marital status belongs to single individuals with the frequency of 269 individuals equal to $69.9 \%$ of the population. The number of married individuals that have participated in this study is 116 individuals equal to $30.1 \%$ of the total responders. Among the responders, the highest frequency in terms of education belongs to individuals with BA/BS with the frequency of 219 individuals equal to $56.9 \%$ of the sample and the lowest number in terms of education is comprised of individuals with $\mathrm{PhD}$ with the frequency of 2 individuals equal to $0.5 \%$ of the sample. Among the responders, the majority of the individuals are in the age range of less than 25 years with the frequency of 186 individuals equal to $48.3 \%$. The lowest frequency in terms of age is related to individuals over 40 years whose number is 7 individuals equal to $1.8 \%$ of the responders.

\subsection{Hypothesis Testing}

In this stage, the relationships between the research constructs can be tested. For this purpose, the considered model was implemented in LISREL Software and by SEM method, by means of 8.80 LISREL Software, the causal relationship between the variables was tested. Based on the fitness indicators of LISREL basic model, the research structural model has good fitness. The square root of the variance estimation of RMSEA error of approximation for the research structural model has been reported as less than 0.08 and the other fitness indicators are also close to the favorable values. Thus, this model has good fitness for testing the hypotheses and it can be considered statistically reliable.

To test the hypotheses, path analysis was used which is a kind of multivariate regression that provides the possibility to explore the causal relationship between two or more variables. Path coefficients and t-values are presented in table 2. To confirm or reject the hypotheses, the coefficient of significance (t-statistic) is used. If t-value is more than 1.64 (at the 5\% level of error), the hypothesis is accepted. Otherwise, the hypothesis is rejected.

Based on the results presented in table 2, the path coefficient of the effect of collectivism on consumer complicity is -0.04 and it has t-value equal to -0.85 . The $t$-value for this parameter has been calculated as less than 1.64. Thus, based on the $5 \%$ error rule in rejection of the null hypothesis for values over 1.64 in each parameter, the null hypothesis model with $95 \%$ confidence is confirmed. So, there is no significant relationship between collectivism and consumer complicity, and collectivism does not affect consumer complicity in buying counterfeits.

It is in contrast with Chaudhry and Stumpf (2011), in which the positive effect of collectivism on consumer complicity was confirmed. Also, the path coefficient of the effect of the hedonic shopping experience on consumer complicity is 0.11 and has a t-value equal to 2.48 which is more than 1.64 . Thus, based on the $5 \%$ error rule in rejection of the null hypothesis 


\section{NI Macrothink}

Business Management and Strategy

ISSN 2157-6068

2017, Vol. 8, No. 1

for values over 1.64 in each parameter, the null hypothesis is rejected with $95 \%$ confidence, and as this coefficient is significant and positive, it can be concluded that there is a direct relationship between hedonic shopping experience and consumer complicity. Therefore, hedonic shopping experience affects consumer complicity. Similarly, other hypothesis were tested which presented in table below.

Table 2. Hypotheses testing and Path coefficients

\begin{tabular}{|c|c|c|c|c|c|}
\hline Hypothesis & Analyzed Path & t-value & Path coefficient & Result & $\begin{array}{c}\text { Prior researches' } \\
\text { result }\end{array}$ \\
\hline H1 & Collectivism $\longrightarrow$ Consumer complicity & -0.85 & -0.04 & Not supported & Supported \\
\hline $\mathrm{H} 2$ & Hedonic shopping experience $\longrightarrow$ Consumer complicity & 2.48 & 0.11 & Supported & Supported \\
\hline H3 & Ethical concern $\longrightarrow \quad$ Consumer complicity & -1.90 & -0.08 & Not supported & Supported \\
\hline H4 & Perceived quality $\longrightarrow$ Consumer complicity & 3.17 & 0.89 & Supported & Supported \\
\hline H5 & Effort expectancy $\longrightarrow$ Consumer complicity & 1.24 & 0.08 & Not supported & Supported \\
\hline H6 & Idealism $\longrightarrow \quad$ Ethical concern & 7.28 & 0.53 & Supported & Supported \\
\hline H7 & Relativism $\longrightarrow$ Ethical concern & -1.46 & -0.10 & Not supported & Not supported \\
\hline H8 & Reliability $\longrightarrow$ Perceived quality & 1.43 & 0.10 & Not supported & Supported \\
\hline H9 & Behavioral loyalty $\longrightarrow$ Perceived quality & 2.72 & 0.42 & Supported & Not supported \\
\hline H10 & Family $\longrightarrow$ perceived quality & 2.44 & 0.30 & Supported & Supported \\
\hline H11 & Price $\longrightarrow$ perceived quality & -2.66 & -0.26 & Not supported & Supported \\
\hline
\end{tabular}

\section{Conclusion}

Based on the results of the first hypothesis, according to which hedonic shopping experience has a positive effect on consumer complicity, it is suggested that marketing managers pay attention to this point that existence of the atmosphere of hedonic shopping for consumers, regarding both physical and also virtual shopping, causes consumer complicity in buying counterfeits to increase. Based on the results of the second hypothesis, the positive effect of collectivism on consumer complicity was not accepted and as this hypothesis regarding counterfeits was confirmed in previous studies, marketing managers should note that collectivism and encouraging other people to consume such products will not have a positive effect on consumer complicity. Based on the results of the third hypothesis that rejects the negative effect of ethical considerations on consumer complicity and as in previous studies regarding counterfeits this hypothesis was confirmed, it can be concluded that at present in our country ethical considerations and moral concerns, unlike our expectations, can't have a negative effect on consumer complicity in consuming this group of products, and marketing managers should pay attention to this important point. Based on the results of the fourth hypothesis, according to which perceived quality has a positive effect on consumer complicity, it is suggested that marketing managers note that existence of a positive image of the quality of the considered product causes consumer complicity in buying counterfeits to increase. Based on the results of the fifth hypothesis, according to which the positive effect of expectations for effort on hedonic shopping experience is rejected, and based on this point 
that in similar studies in other countries this hypothesis was confirmed with regard to other products, it seems that finding a place to provide counterfeits and the features and advantages that buying from the vendors of such products can entail is not an issue to engage the mind of consumers of counterfeits in our country and can't affect the hedonic shopping experience of this group of products either. Based on the results of the sixth hypothesis, according to which idealism has a positive effect on ethical considerations, it is suggested that marketing managers always note that moral principles that are accepted by the majority of consumers should be identified, since they can be a way to prevent from the sale of counterfeits and affect ethical considerations of consumers for buying this group of products. It should be noted that this hypothesis was confirmed in similar studies regarding the same group of products and it was also expected to be confirmed in this study.

The results of the seventh hypothesis, according to which relativism has a negative effect on ethical considerations, show that as was expected, like previous studies on the same group of products, this hypothesis was rejected and this means that cultural and geographical differences and each individual's perception of ethics can't have a negative effect on ethical considerations for using counterfeits. Based on the rejection of the eighth hypothesis, according to which reputation has a positive effect on perceived quality, and as in previous studies on other products this hypothesis was confirmed, it seems that regarding counterfeits, issues such as health and safety, reliability and convenient services can't have a positive effect on perceived quality of this group of products.

Based on the results of the ninth hypothesis, according to which behavioral loyalty has a positive effect on perceived quality, it is suggested that marketing managers note that creating loyalty to a product may be one of the effective factors for creation of a positive image of the quality of that product in the consumer's mind. In fact, even if consumers are loyal to the use of counterfeits, a good quality of this group of products will be created in their mind. Based on the results of the tenth hypothesis, according to which family has a positive effect on perceived quality, it is suggested that marketing managers note, more than before, that if one of the family members has a positive attitude towards a product, this can be effective in influencing the other family members for creation of the positive image of a product in their mind. Confirmation of this hypothesis, as its confirmation in previous studies, shows that family members have a special effect on creation of a proper image of the quality of counterfeits in the consumer's mind. Based on the results of the eleventh hypothesis, according to which the positive effect of price on perceived quality is rejected and price has a negative effect on perceived quality, and based on the confirmation of this hypothesis regarding other products in previous studies, it seems that the factor of price regarding counterfeits can't have a positive effect on perceived quality of such products.

\section{Limitation and Future Research}

Due to inconsistencies in the results of the first, third, fifth, seventh, eighth and eleventh hypotheses with theoretical literature, it is suggested that the reasons for this issue be investigated in the future studies. Further, the great diversity of the factors affecting consumer 
complicity in buying counterfeits, it is suggested that other factors be also investigated in future studies. It is suggested that such studies be done in a wider range and at the national level, so that appropriate strategies and plans can be formulated. It is suggested that, due to the wide range of counterfeits, researchers also investigate other counterfeits in the future studies.

\section{References}

Babin, B. J., Darden, W. R., \& Griffin, M. (1994). Work and/or fun: measuring hedonic and utilitarian shopping value”. Journal of Consumer Research, 20, 644-56.

Berman B. (2008). Strategies to detect and reduce counterfeiting activity, Kelley School of Business, Indiana University.

Bian, X., \& Moutinho, L. (2011). Counterfeits and branded products: effects of counterfeit ownership, Journal of Product \& Brand Management, 20(5), 379-393. http://dx.doi.org/10.1108/10610421111157900

Broyles, S. A., Leingpibul, T., Ross, R. H., \& Foster, B. M. (2010). Brand equity's antecedent/consequence relationships in cross-cultural settings. Journal of Product \& Brand Management, 19(3), 159-169. Retrieved from www.emeraldinsight.com/1061-0421.htm

Chaudhry, P. E., \& Stumpf, S. A. (2011). Consumer complicity with counterfeit products. Journal of Consumer Marketing, 28(2), 139-151. www.emeraldinsight.com/0736-3761.htm

Childers, T., \& Rao, A. (1992). The influence of familial and peer-based reference groups on consumer decisions. Journal of Consumer Research, 19(2), 198-211.

Cobb-Walgren, C. J., Ruble, C. A., \& Donthu, N. (1995). Brand equity, brand preference and purchase intent. Journal of Advertising, 24(3), 25-41.

De Matos C. D., Ituassu, C. T., \& Rossi, C. A. V. (2007). Consumer attitudes toward counterfeits: a review and extension. Journal of Consumer Marketing, 24(1), 36-47. http://dx.doi.org/10.1108/07363760710720975

Dubinsky, A. L., Nataraajan, R., \& Huang, W. Y. (2005). Consumers' moral philosophies: identifying the idealist and the relativist. Journal of Business Research, 58(12), 1690-701.

Eisend, M., \& Schuchert-Güler, P. (2006). Explaining counterfeit purchases: a review and preview, Academy of Marketing Science Review, 12, 1-22.

Feltham, T. S. (1998). Leaving home: brand purchase influences on young adults, Journal of Consumer Marketing, 15(4), 372-85.

Gentry, J., Putrevu, S., \& Shultz, C. (2006). The effects of counterfeiting on consumer search. Journal of Consumer Behaviour, 5, 1-12.

Gil, R. B., Andre's, E. F., \& Salinas, E. M. (2007). Family as a source of consumer-based brand equity. Journal of Product \& Brand Management, 16(3), 188-199. Retrieved from www.emeraldinsight.com/1061-0421.htm

Gupta, P., Gould, S., \& Pola, B. (2004). To pirate or not to pirate: a comparative study of the ethical versus other influences on the consumer's software acquisition-mode decision. 
Journal of Business Ethics, 55(3), 255-74.

Hirschman, E. C., \& Holbrook. M. B. (1982). Hedonic consumption: emerging concepts, methods and propositions. Journal of Marketing, 46, 92-101.

Hofstede, G. (1980). Culture's Consequences: International Differences in Work-related Values, Sage, Newbury Park, CA.

Husted, B. W. (2001). The impact of national culture on software piracy. Journal of Business Ethics, 26(3), 197-211.

Keillor, B. D., Parker, S., \& Schaeffer, A. (1996). Influences on adolescent brand preferences in the United States and Mexico. Journal of Advertising Research, 20, 47-56.

Keller, K. L. (2003). Strategic Brand Management: Building, Measuring, and Managing Brand Equity, Prentice-Hall, Upper Saddle River, NJ.

Kirmani, A., \& Wright, P. (1989). Money talks: perceived advertising expense and expected product quality. Journal of Consumer Research, 16(3), 344-54.

Krejcie, R. V., \& Morgan, D. W. (1970). Determining sample size for research activities, Educational and Psychological Measurement, 30, 607-610

Lee, J. (2009). Understanding College Students' Purchase Behavior of Fashion Counterfeits: Fashion Consciousness, Public Self-Consciousness, Ethical Obligation, Ethical Judgment, and the Theory of Planned Behavior. The School of Human and Consumer Sciences and the College of Health and Human Services, 3-65.

Lysonski, S., \& Durvasula, S. (2008). Digital piracy of MP3s: consumer and ethical predispositions. Journal of Consumer Marketing, 25(3), 167-78.

Milgrom, P., \& Roberts, J. (1986). Price and advertising signals of product quality. Journal of Political Economy, 55, 10-25.

Moore ES, Wilkie WL, Lutz, RJ. (2002). Passing the torch: intergenerational influences as a source of brand equity. Journal of Marketing, 66, 17-37.

OCED. (2009). Magnitude of Counterfeiting and Piracy of Tangible Products: An Update, Paris.

Parasuraman, A., Zeithaml, V. A., \& Berry, L. L. (1985). A conceptual model of service quality and its implications for future research. Journal of Marketing, 49(4), 41-50.

Penz E, Stöttinger B. (2008). Corporate image and product similarity - assessing major demand drivers for counterfeits in a multi-country study. Psychology \& Marketing, 25(4), $352-81$.

Rao AR, Monroe, KB. (1989). The effect of price, brand name, and store name on buyers' perceptions of product quality: an integrative review. Journal of Marketing Research, 26, $351-7$.

Shoham A, Ruvio A, Davidow M. (2008). (Un)ethical consumer behavior: Robin Hoods or plain hoods? Journal of Consumer Marketing, 24(4), 200-10. 
Singh JJ, Vitell SJ, Al-Khatib J, \& Clark I. (2007). The role of moral intensity and personal moral philosophies in the ethical decision making of marketers: a cross-cultural comparison of China and United States. Journal of International Marketing, 15(2), 86-112.

Steenhaut S, Van Kenhove P. (2006). An empirical investigation of the relationships among a consumer's personal values, ethical ideology and ethical beliefs. Journal of Business Ethics, 64(2), 137-55.

Tan B. (2002). Understanding consumer ethical decision making with respect to purchase of pirated software. Journal of Consumer Marketing, 19(2/3), 96-110.

Tracey SD, Meredith ED. (2010). Uncovering the Real Effect of Switching Costs on the Satisfaction-Loyalty Association: The Critical Role of Involvement and Relationship Benefits. European Journal of Marketing, 46(3/4), 447-468.

Wang F, Zhang H, Zang H, Ouyang M. (2005). Purchasing pirated software: an initial examination of Chinese consumers. Journal of Consumer Marketing, 22(6), 340-51.

Wee, C. H., Tan, S. J., \& Cheok, H. (1995). Non-price determinants of intention to purchase intention to purchase. Journal of International Marketing Review, 12(6), 19-46.

Wilcox K, Kim H. M., \& Sen, S. (2009). Why do consumers buy counterfeit luxury brands?. Journal of Marketing Research, 46, 247-59.

Yang K. (2010). Determinants of US consumer mobile shopping services adoption: implications for designing mobile shopping services. Journal of Consumer Marketing, 27(3), 262 - 27. Retrieved from www.emeraldinsight.com/0736-3761.htm

\section{Glossary}

AAB Device: an equipment for sky.

KKD Device: an equipment for shipping.

\section{Appendix}

Appendix 1. Survey Questionnair's Items

\begin{tabular}{|l|l|}
\hline \multirow{2}{*}{ Idealism } & $\begin{array}{l}\text { A person should make certain that their actions never intentionally harm } \\
\text { another even to a small degree. }\end{array}$ \\
\cline { 2 - 3 } & $\begin{array}{l}\text { One should never psychologically or physically harm another person. } \\
\text { One should not perform an action which might in any way threaten the } \\
\text { dignity and welfare of another individual. }\end{array}$ \\
\cline { 2 - 2 } & If an action could harm an innocent other, then it should not be done.
\end{tabular}




\begin{tabular}{|c|c|}
\hline & It is never necessary to sacrifice the welfare of others. \\
\hline \multirow[t]{5}{*}{ Relativism } & Codes of ethics should reflect cultural differences. \\
\hline & What is ethical varies from one situation and society to another. \\
\hline & $\begin{array}{l}\text { Questions of what is ethical for everyone can never be resolved since what } \\
\text { is moral or immoral is up to the individual. }\end{array}$ \\
\hline & Moral standards indicate how a person should behave in a particular culture. \\
\hline & $\begin{array}{l}\text { Whether a lie is judged to be moral or immoral depends upon the } \\
\text { circumstances surrounding the actions. }\end{array}$ \\
\hline \multirow[t]{3}{*}{ Collectivism } & He that shares is to be rewarded, even if it not theirs to share. \\
\hline & $\begin{array}{l}\text { I wish others can share with me, even if they do not want what they are } \\
\text { sharing. }\end{array}$ \\
\hline & The more people share a product, the more valuable the product is. \\
\hline \multirow{4}{*}{$\begin{array}{l}\text { Ethical } \\
\text { concern }\end{array}$} & Movie counterfeiting infringes on intellectual property rights. \\
\hline & Movie counterfeiting damages the movie industry. \\
\hline & Obtaining counterfeit movies is illegal. \\
\hline & Obtaining counterfeit movies is unethical. \\
\hline \multirow{3}{*}{$\begin{array}{l}\text { Perceived } \\
\text { quality }\end{array}$} & Counterfeit movies have a similar quality to the legal version. \\
\hline & Counterfeit movies are as reliable as the legal version. \\
\hline & The quality of counterfeit movies are very high. \\
\hline \multirow{2}{*}{$\begin{array}{l}\text { Hedonic } \\
\text { Shopping }\end{array}$} & I would shop, not because I had to, but because I wanted to. \\
\hline & $\begin{array}{l}\text { Compared to other things I could do, the time spent shopping would be } \\
\text { enjoyable. }\end{array}$ \\
\hline
\end{tabular}




\begin{tabular}{|c|c|}
\hline & $\begin{array}{l}\text { I would have a good time because I would be able to act on the "spur of the } \\
\text { moment" }\end{array}$ \\
\hline & While shopping, I would feel a sense of adventure. \\
\hline & $\begin{array}{l}\text { I would not worry about legal prosecution since I would use cash to pay for } \\
\text { the counterfeit goods. }\end{array}$ \\
\hline & $\begin{array}{l}\text { I would shop for counterfeits on the web, not because I had to, but because I } \\
\text { wanted to }\end{array}$ \\
\hline & $\begin{array}{l}\text { Compared to other things I could do, the time spent surfing for counterfeits } \\
\text { would be enjoyable }\end{array}$ \\
\hline & $\begin{array}{l}\text { I would have a good time because I would be able to act on the "spur of the } \\
\text { moment" }\end{array}$ \\
\hline & $\begin{array}{l}\text { While surfing the internet, I would feel a sense of adventure. I would not } \\
\text { worry about legal prosecution since many of the counterfeit items would be } \\
\text { a free download from the web }\end{array}$ \\
\hline Consumer & I would obtain counterfeit movies on the internet \\
\hline & I would encourage friends to obtain counterfeit movies \\
\hline & I would consider giving a counterfeit movie to a friend \\
\hline & I would obtain counterfeit movies from a vendor or at a market \\
\hline Price & The price of counterfeit movies are high $(\mathrm{R})$ \\
\hline & Counterfeit movie is cheap in relation to original one \\
\hline & Counterfeit movies are expensive $(\mathrm{R})$ \\
\hline Family & My parents have bought counterfeit movies for a long time \\
\hline & I have seen my parents buying counterfeit movies in many occasions \\
\hline & Counterfeit movies has been at home since I was a child \\
\hline
\end{tabular}




\begin{tabular}{|c|c|}
\hline & $\begin{array}{l}\text { My parents recommended me to buy counterfeit movies, whenever I intend } \\
\text { to buy a movie. }\end{array}$ \\
\hline & My parents' opinion is that shopping counterfeit movie is a good \\
\hline Effort & Purchasing process of counterfeit movies would be clear and understandable \\
\hline & I would find counterfeit movies easy \\
\hline & It would be easy for me to shopping counterfeit movies. \\
\hline Behavioral & I say positive things about the counterfeit movie to other people. \\
\hline & $\begin{array}{l}\text { I consider the counterfeit movie my first choice when I want to purchase the } \\
\text { movie. }\end{array}$ \\
\hline & I will continue to purchase the counterfeit movie for the next few years. \\
\hline & I am loyal to the counterfeit movie. \\
\hline Reliability & Counterfeit movies are in good condition. \\
\hline & Counterfeit movies are reliable. \\
\hline & Providers emphasize the quality of the counterfeit movies. \\
\hline & Providers of counterfeit movies seek for presenting good quality. \\
\hline
\end{tabular}

Appendix 2. Model of Population

\section{Copyright Disclaimer}

Copyright for this article is retained by the author(s), with first publication rights granted to the journal.

This is an open-access article distributed under the terms and conditions of the Creative Commons Attribution license (http://creativecommons.org/licenses/by/3.0/). 